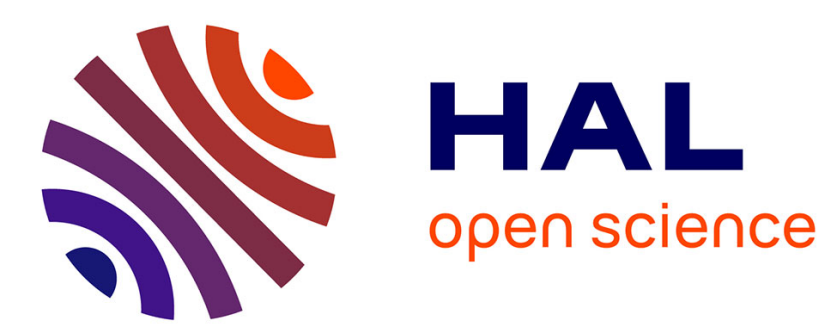

\title{
Trophic ecology of mullets during their spring migration in a European salt marsh: A stable isotope study
}

\author{
Benoit Lebreton, Pierre Richard, Emmanuel Parlier, Gaël Guillou, Gérard
} Blanchard

\section{- To cite this version:}

Benoit Lebreton, Pierre Richard, Emmanuel Parlier, Gaël Guillou, Gérard Blanchard. Trophic ecology of mullets during their spring migration in a European salt marsh: A stable isotope study. Estuarine, Coastal and Shelf Science, 2011, pp.502-510. hal-01080306

\section{HAL Id: hal-01080306 https://hal.science/hal-01080306}

Submitted on 5 Nov 2014

HAL is a multi-disciplinary open access archive for the deposit and dissemination of scientific research documents, whether they are published or not. The documents may come from teaching and research institutions in France or abroad, or from public or private research centers.
L'archive ouverte pluridisciplinaire HAL, est destinée au dépôt et à la diffusion de documents scientifiques de niveau recherche, publiés ou non, émanant des établissements d'enseignement et de recherche français ou étrangers, des laboratoires publics ou privés. 


\section{Trophic ecology of mullets during their spring migration in a}

\section{European salt marsh: A stable isotope study}

Benoit Lebreton $^{\mathrm{a}, 1^{*}}$, Pierre Richard ${ }^{\mathrm{a}}$, Emmanuel P. Parlier ${ }^{\mathrm{a}, 2}$, Gaël Guillou ${ }^{\mathrm{a}}$, Gérard F. Blanchard $^{\mathrm{a}}$

${ }^{\mathrm{a}}$ : UMR Littoral, Environnement et Sociétés (LIENSs), UMR 6250 CNRS-Université de La Rochelle, Institut du Littoral et de l'Environnement, 2 rue Olympe de Gouges, 17000 La Rochelle, France

*: Corresponding author: benoit.lebreton@univ-lr.fr, phone: + 33 (0)5 465076 61, fax: + 33

(0)5 46507663

${ }^{1}$ : Present address: Harte Research Institute for Gulf of Mexico Studies, Texas A \& M University - Corpus Christi, 6300 Ocean Drive, Corpus Christi, TX 78412- 5869, USA

2: Present address: Parlier environnement SAS, Pôle technologique, 40 rue Chef de Baie, 17000 La Rochelle, France

E-mail :

Pierre Richard: pierre.richard01@univ-lr.fr;

Emmanuel P. Parlier: emmanuel.parlier@yahoo.fr;

\footnotetext{
Abbreviations:

CPUE: Catch per unit effort

$\mathrm{CPUE}_{\mathrm{n}}$ : Number CPUE

$\mathrm{CPUE}_{\mathrm{m}}$ : Biomass CPUE

DTW: Digestive tract weight

G0: Young-of-the-year

G1: 1-year olds

G2: 2-year olds

G3+: 3-year-old and older

IR: Instantaneous ration

SPOM: Suspended particulate organic matter

SSOM: Surface sediment organic matter

TW: Total fish weight

VI: Vacuity index

Gaël Guillou: gael.guillou@univ-lr.fr;
} 
Gérard F. Blanchard: gerard.blanchard@univ-lr.fr

\begin{abstract}
Mullet populations are abundant in littoral waters throughout the world and play a significant role in organic matter fluxes. Mullets are opportunistic feeders: adults have frequently been shown to feed on primary producers (e. g. fresh or detrital plant material, microphytobenthos) but they may also feed on meiofauna. The population structure and stomach contents of mullets that colonize salt marsh creeks in Aiguillon Bay (French Atlantic coast) were studied to determine if they use salt marshes as a feeding ground in spring. Stable isotope analyses were carried out on mullets sampled to assess their diet during their spring migration. The mullet population was primarily composed of young-of-the-year (G0), 1-year old (G1) of both Liza ramada and Liza aurata species and 3-year-old or older (G3+) L. ramada individuals. $\mathrm{G} 0$ and $\mathrm{G} 3+$ population densities increased during the spring period: catch per unit effort (CPUE) increased from 0.22 to 1.49 ind. in $^{-1}$ for the $\mathrm{G} 0$ age group; but stomach content analyses revealed that only G1 and G3+ feed in the salt marsh. Isotopic signatures of G1 (spring: $\delta^{13} \mathrm{C}:-14.8 \%, \delta^{15} \mathrm{~N}: 14.1 \%$ ) and $\mathrm{G} 3+$ mullets (spring: $\delta^{13} \mathrm{C}$ : $16.9 \%, \delta^{15} \mathrm{~N}: 13.8 \%$ ) indicate that mullet growth is supported largely by primary consumers, such as benthic meiofauna or small macrofauna. Mullets are thus positioned at a much higher trophic level than true primary consumers.
\end{abstract}

\title{
KEY WORDS
}

Mugilidae; Salt marsh; Diet; Stable isotope analysis; Stomach content; Food web; European Atlantic coasts

\section{INTRODUCTION}

Mullets are important members of fish communities in estuarine and littoral waters throughout the world. The study of their feeding activity is of particular interest for a better understanding of ecosystem functioning because they are among the few large fish able to feed directly on the lowest trophic levels (Hickling, 1970; Odum, 1970; Laffaille et al., 2002; Gautier and Hussenot, 2005). They inhabit numerous habitats in the littoral zone: mudflats (Almeida et al., 1993), salt marshes (Lefeuvre et al., 1999; Laffaille et al., 2002) as well as estuaries and even rivers (Lam Hoï, 1969; Keith and Allardi, 2001; Cardona, 2006). Depending on their habitat, mullets can have many feeding strategies (e. g. water filtering, 
sediment scraping...) (Bruslé, 1981; Almeida et al., 1993; Cardona, 1995) to exploit the most accessible food resources, in terms both of quantity and quality (Odum, 1968; Almeida et al., 1993). Due to their high biomass in European salt marshes, (Laffaille et al., 2000; Parlier et al., 2006), mullets play a major role in coastal food webs as biotic vectors of organic matter between littoral habitats and the open sea (Lefeuvre et al., 1999; Laffaille et al., 2002) and also as competitors with other consumers for food resources (Lasserre et al., 1976).

On European Atlantic coasts, mullets spend their reproduction period off-shore, on the continental shelf. Spawning occurs at different periods depending on location and species: from August to February for $L$. aurata and from fall to winter for L. ramada (Keith, 2001). Recruitment also varies in coastal areas depending on species and generally lasts from the end of winter through summer (Hickling, 1970; Gautier and Hussenot, 2005). During that period, young-of-the-year shift from a planktonic to a benthic diet (Albertini-Berhaut, 1973, 1974; Ceccherelli et al., 1981; Ferrari and Chieregato, 1981).

Adult mullets also migrate in early spring to the very littoral areas where they perform daily trophic migrations. They can exploit the full extent of the mudflats, including the lower part of salt marsh, they can reach via the numerous creeks and channels that fill up at every high tide (Laffaille et al., 2000; Parlier et al., 2006). Stomach content analyses tend to show that mullets have a limno-benthophagous feeding mode in these areas: when foraging, they scrap the superficial sediment layers and ingest a mix of sediment and organic matter. Food selection is achieved by the mechanical (gill-rakers) and gustatory elements (Bruslé, 1981).

Trophic ecology of mullets has been most often studied through stomach content analysis. Although it provides considerable information on fish food resources, stomach content analysis only reveals what has been recently ingested. Stable isotope analyses of tissues are complementary to stomach content studies since they allow the determination of what is actually assimilated (Pinnegar and Polunin, 1999). Stable isotope analyses can also be used to assess changes of diet during migrations (Fry, 2006). The distinction between ingested and assimilated resources is important for mullets because their limno-benthophagous feeding strategy leads them to ingest a large variety of available food items of different degrees of digestibility, including plants or detrital matter (Odum, 1970; Bruslé, 1981), microalgae (Almeida et al., 1993; Laffaille et al., 2002), but also meiofauna (Ezzat, 1963; Lasserre et al., 1976; Laffaille et al., 1998) and small macrofauna (Riera et al., 1999; Bouchard and Lefeuvre, 2000; Quan et al., 2007). Assimilation processes are related to the quality, and thus the digestibility of ingested food items, with better assimilation rates for fresh tissues or tissues with higher nitrogen or nutrient content (Tenore, 1983; Mann, 1988; Cebrián, 1999). 
This study was conducted to determine the origin of food sources and the trophic level of

mullets. It has been carried out in the salt marshes of the Aiguillon bay, an intertidal bay on the French Atlantic coast, in which salt marshes are in the same type of these which have previously been examined using stomach content analyses (Laffaille et al., 1998; Laffaille et al., 2002). Mullet abundance is high in this bay during the spring (Parlier et al., 2006), when mullets colonize salt marsh creeks after a winter stay in off-shore waters (Laffaille et al., 1998). In this study, the population structure of mullets was determined to define which age groups colonize the salt marsh creeks. The feeding activity of each age group entering and leaving the creeks was analyzed by comparing stomach content weight between flood and ebb tides. The instantaneous and long-term diets were determined using stable isotope analyses of stomach content and muscle tissues, respectively.

\section{MATERIALS AND METHODS}

\subsection{Study site}

Aiguillon Bay, located on the French Atlantic coast, is an bay of $56 \mathrm{~km}^{2}$ in area and includes $38 \mathrm{~km}^{2}$ of bare mudflats and $18 \mathrm{~km}^{2}$ of salt marshes (Fig. 1) (Verger, 2005). This bay is a semi-diurnal macrotidal system, which causes relatively strong tidal currents (average 0.2-0.6 m.s $\left.{ }^{-1}\right)$ (SHOM, 2001). The bay receives most of effluents of the Marais Poitevin, the second largest wetland in France. Freshwater inputs come from the Sèvre Niortaise River, the Lay River and many channels, including the largest, the Curé Channel. Watershed inputs occur mainly from autumn to spring (Meunier and Joyeux, unpublished results). Salinity ranged from 4.5 to 35 during our spring sampling period.

Mullets were collected in a tributary creek of the Curé Channel (Fig. 1). This creek drains a 10 ha watershed on the southern part of Aiguillon Bay (Parlier et al., 2006). The whole creek is integrated in the salt marsh part of the bay, dominated by halophytic plants, such as Halimione portulacoides (Meunier and Joyeux, unpublished results). No vegetation was present on creek banks, which were covered with wide patches of microphytobenthos. The sampling site $\left(46^{\circ} 15^{\prime} 49 \mathrm{~N}, 01^{\circ} 07^{\prime} 09 \mathrm{~W}\right)$ was located $50 \mathrm{~m}$ upstream from the creek mouth and had a cross-section of $15 \mathrm{~m}$ wide and $5 \mathrm{~m}$ deep.

\subsection{Fish sampling}

Mullets were regularly sampled during three non-consecutive weeks from the beginning of March to mid-April 2005 (Spring 1: March 8 to 14; Spring 2: March 24 to 30; Spring 3: 
April 6 to 12). Sampling was performed during spring tides, with tidal ranges from 5.70 to $6.25 \mathrm{~m}$ as in the study of Parlier et al. (2006). A total of 22 fish samplings were carried out during the three sampling weeks to determine the population structure with precision and to obtain enough samples for stomach content and stable isotope analyses (muscle tissues and stomach contents). In order to compare stomach contents of mullets before and after their visit to the salt marsh creek, 16 fish samplings were performed at ebb tide and 6 at flood tide (Laffaille et al., 2002).

The whole mullet community was sampled by using a series of four successive nets in the creek (Laffaille et al., 1998; Parlier et al., 2006): three trammel nets (70 to $30 \mathrm{~mm}$ mesh size, $2 \mathrm{~m}$ high and $30 \mathrm{~m}$ long) to capture large individuals and a fyke net $(4 \mathrm{~mm}$ mesh size, $5 \mathrm{~m}$ deep, $1.80 \mathrm{~m}$ high, $20 \mathrm{~m}$ long) to catch the smallest individuals. To ensure maximum adult capture rates, trammel nets were set out diagonally across the creek and spaced $10 \mathrm{~m}$ apart because adult mullets can avoid nets and thereby escape (Laffaille et al., 2002). For ebb tide sampling, nets were set out across the creek at high tide until the creek was totally drained. Nets were set up on the creek for periods of 20 minutes separated by intervals of 5 minutes; sampling was therefore efficient for $80 \%$ of the tide. Using this kind of protocol, the number and biomass of fish which migrate into the creek during one tidal cycle can be estimated (Laffaille et al., 1998). Moreover, with this regular sampling, mullets can be frozen quickly, thereby arresting digestion and avoiding regurgitation. For flood tide sampling, nets were set across the empty creek and were left until high tide. The sampling protocol was the same as for the ebb tide. All samples were stored in iceboxes in the field and deep frozen $\left(-20^{\circ} \mathrm{C}\right)$ at the laboratory until analysis.

\subsection{Population structure}

All sampled mullets were measured (fork length) to the nearest $\mathrm{mm}$. Mullets of $50 \mathrm{~mm}$ length or more were identified to the species level using the identification keys of Farrugio (1977), Cambrony (1984), synthesized in Gautier and Hussenot (2005), and Keith and Allardi (2001). Mullets were individually weighed to the nearest $0.01 \mathrm{~g}$. Mullets less than $50 \mathrm{~mm}$ long, for which identification is very difficult (Cambrony, 1984; Keith and Allardi, 2001), were not identified. These mullets were pooled into size classes to the nearest $\mathrm{mm}$ and mean individual weights were calculated for each size class $( \pm 0.01 \mathrm{~g})$. Within species, age was defined based on growth curves from Le Dantec (1955) and Lam Hoï (1969), tables in Gautier and Hussenot (2005) and young-of-the-year growth curves for Liza aurata and Liza ramada from Aiguillon Bay (Parlier, unpublished results). 
For all ebb samples (one sample corresponds to a period of 20 minutes), the number $\left(\mathrm{N}_{\mathrm{i}}\right)$ and biomass $\left(\mathrm{M}_{\mathrm{i}}\right)$ of mullets per sample were defined for each species and each age group (Laffaille et al., 1998). Numbers of non-caught mullets $\left(\mathrm{N}_{\mathrm{j}}\right)$ during the 5 minute intervals between samples $i$ and $i+1$ were estimated by extrapolation using the moving average of samples $\left(\mathrm{N}_{\mathrm{i}}\right.$ and $\left.\mathrm{N}_{\mathrm{i}+1}\right)$ with the formula: $\mathrm{N}_{\mathrm{j}}=\left[\left[\left(\mathrm{N}_{\mathrm{i}} / \mathrm{t}_{\mathrm{i}}\right)+\left(\mathrm{N}_{\mathrm{i}+1} / \mathrm{t}_{\mathrm{i}+1}\right)\right] / 2\right] * \mathrm{t}_{\mathrm{j}}$ where $\mathrm{t}_{\mathrm{i}}$ is the sampling time for sample $i(\min ), t_{i+1}$ : sampling time for sample $i+1(\min )$ and $t_{j}$ is the time between sample $i$ and $i+1(\mathrm{~min})$. Biomass of non-caught mullets per sample $\left(\mathrm{M}_{\mathrm{j}}\right)$ was determined using $\mathrm{M}_{\mathrm{i}}$ and the same calculations. Total number $\left(\Sigma \mathrm{N}_{\mathrm{i}}+\Sigma \mathrm{N}_{\mathrm{j}}\right)$ and biomass $\left(\Sigma \mathrm{M}_{\mathrm{i}}+\Sigma \mathrm{M}_{\mathrm{j}}\right)$ of mullets were calculated per species and per age group for each ebb fish sampling. For each ebb fish sampling, catch per unit effort (CPUE), i.e. the number (CPUE $\left.{ }_{n}\right)$ or biomass $\left(\mathrm{CPUE}_{\mathrm{m}}\right)$ of mullets caught per minute of sampling, was calculated for each species and cohort using the formulas (Laffaille et al., 1998): CPUE $_{n}=\left(\Sigma \mathrm{N}_{\mathrm{i}}+\Sigma \mathrm{N}_{\mathrm{j}}\right) /\left(\Sigma \mathrm{t}_{\mathrm{i}}+\Sigma \mathrm{t}_{\mathrm{j}}\right)$ and $\operatorname{CPUE}_{\mathrm{m}}=\left(\Sigma \mathrm{M}_{\mathrm{i}}+\Sigma \mathrm{M}_{\mathrm{j}}\right) /\left(\Sigma \mathrm{t}_{\mathrm{i}}+\Sigma \mathrm{t}_{\mathrm{j}}\right)$.

\subsection{Stomach content analysis}

A total of 123 stomach contents of mullets less than $50 \mathrm{~mm}$ long were sampled among the three sampling weeks (flood tides, $\mathrm{n}=55$; ebb tides, $\mathrm{n}=68$ ). The stomach contents of these fish were too small to be weighted with enough accuracy, so whole digestive tracts were dissected under a stereomicroscope $(\times 20)$ and weighed. The ratio between digestive tract weight (DTW, $\pm 0.0001 \mathrm{~g}$ ) and total fish weight (TW, $\pm 0.0001 \mathrm{~g}$ ) was calculated to compare mullets sampled at flood tide and at ebb tide. Non-parametric unilateral Wilcoxon tests were used to test the differences in these ratios between flood tide and ebb tide $\left(\mathrm{H}_{1}\right.$ : DTW/TW at flood tide $<$ DTW $/$ TW at ebb tide).

Digestive tracts of mullets of $50 \mathrm{~mm}$ long or more were regularly collected on mullets sampled at flood tide $(\mathrm{n}=123)$ and ebb tides $(\mathrm{n}=131)$. Percentages of empty stomachs (vacuity index, VI) were determined and compared between flood tide and ebb tide with Chisquare tests. The whole stomach contents were weighed $( \pm 0.01 \mathrm{~g})$ and ratios between stomach content fresh weight and total fish fresh weight (instantaneous ration, IR) were determined. Differences in IR of mullets per cohort and species between flood tide and ebb tide were tested using non-parametric Wilcoxon tests.

\subsection{Stable isotope ratio analysis}

Samples of each age group and of each species for mullets $>50 \mathrm{~mm}$ long were collected during the three sampling weeks. Stomach contents and white dorsal muscle tissues were 
collected to determine the instantaneous and the long-term diets of mullets, respectively.

Muscles were dissected with the highest care to avoid the presence of bone pieces. For smaller mullets ( $<50 \mathrm{~mm}$ long), the mass of the stomach contents was too small for the stable isotope analysis and fish analyses were performed on whole eviscerated and topped fish. All samples were freeze-dried and ground using a ball mill. Fish samples from mullets $<50 \mathrm{~mm}$ and all stomach contents were acidified with 1 mol. $\mathrm{L}^{-1} \mathrm{HCl}$ to remove carbonates then dried in a dry bath at $60^{\circ} \mathrm{C}$ and ground again. Since acidification may have an effect on $\delta^{15} \mathrm{~N}$ values, these samples were analyzed separately for $\delta^{13} \mathrm{C}$ (acidified samples) and $\delta^{15} \mathrm{~N}$ (raw samples). No delipidation was performed on samples since no significant effect on isotope values was noticed during preliminary tests on the different fish class sizes.

Fish isotopic signatures were compared with signatures of food sources from Riera et al. (1999) and from Richard (Unpublished results). Other food sources were hand-picked directly from fresh stomach contents with a stereomicroscope and Dumont \#55 forceps: nematodes (sample of 200 individuals), annelids (sample of 50 individuals) and plant detritus and treated as above.

Samples were analyzed using an EA-IRMS (Isoprime, Micromass, UK). Isotopic values were expressed in the $\delta$ unit notation as deviations from standards (Vienna Pee Dee Belemnite for $\delta^{13} \mathrm{C}$ and atmospheric $\mathrm{N}_{2}$ for $\left.\delta^{15} \mathrm{~N}\right)$ following the formula: $\delta^{13} \mathrm{C}$ or $\delta^{15} \mathrm{~N}=\left[\left(R_{\text {sample/ }} R_{\text {standard }}\right)-\right.$ 1] $\times 10^{3}$, where $R$ is ${ }^{13} \mathrm{C} /{ }^{12} \mathrm{C}$ or ${ }^{15} \mathrm{~N} /{ }^{14} \mathrm{~N}$. The analytical precision for the measurement was $0.15 \%$ for carbon and $0.2 \%$ for nitrogen. Stable isotope signatures were compared with nonparametric Wilcoxon tests.

\section{RESULTS}

\subsection{Population structure}

From the 16 ebb and the 6 flood fish samplings carried out, 1748 mullets were captured. Among individuals with fork length $\geq 50 \mathrm{~mm}, 131$ Liza ramada and 59 Liza aurata were identified. Four age-groups were distinguished (Fig. 2, Table 1): young-of-the-year (G0), 1 year old mullets (G1), 2 year-old mullets (G2) and 3 year-old or older mullets (G3+), the G3+ group being exclusively composed of $L$. ramada.

G0 represented the main percentage (50.9 to $96.9 \%$ ) on the population at each sampling and their mean $\mathrm{CPUE}_{\mathrm{n}}$ increased from 0.22 to 1.49 ind. $\mathrm{min}^{-1}$ between Spring 1 and Spring 3 sampling weeks (Table 1). The G1 age group was dominated by L. ramada and represented the second most abundant age group. G2 individuals from either species were very rare. $L$. 
ramada $\mathrm{G} 3+$ represented a very small proportion of the population, with the highest G3+ $\mathrm{CPUE}_{\mathrm{n}}$ being 0.01 ind. $\mathrm{min}^{-1}$, corresponding to 0.9 to $1.2 \%$ of total densities. Nevertheless, their $\mathrm{CPUE}_{\mathrm{m}}$ accounted for the largest proportion of total population biomass, representing between 56.2 and $96.6 \%$. Biomass proportions of other groups were extremely low except during Spring 1 sampling, when the sum of G1 accounted for $32.9 \%$ of the population biomass (Table 1).

\subsection{Stomach content analyses}

For $<50 \mathrm{~mm}$ mullets, DTW/TW ratios were $8.6 \pm 3.5(\mathrm{n}=55)$ at flood tide and $8.7 \pm 5.5$ $(\mathrm{n}=68)$ at ebb tide and there was no difference in whole digestive tract weights between mullets sampled at flood and ebb tides $(\mathrm{p}=0.955)$. All of the 153 studied digestive tracts were orange-colored and only four presented light traces of sediment.

For $\geq 50 \mathrm{~mm}$ mullets, $L$. ramada $\mathrm{G} 1$ had lower VI at ebb tide, when they left the salt marsh creek, than at flood tide (Table 2). No significant differences in VI were observed between ebb and flood tides for $L$. aurata $\mathrm{G} 1$ and $L$. ramada $\mathrm{G} 2$ and $\mathrm{G} 3+$ groups. Numerous G1 individuals sampled at flood tide were indeed characterized by light food traces in the cardiac part of their stomach, explaining the lack of differences in VI between flood and ebb tides. Except $L$. ramada $\mathrm{G} 2$, age groups of both species presented much higher IR at ebb than at flood tide and very low IR values (ranging from 0 to $1 \%$ ) were much more frequently observed at flood tides than at ebb tide (Table 2). At flood tide, the highest IR values were measured in $L$. ramada $\mathrm{G} 3+$. The number of $L$. aurata $\mathrm{G} 2$ stomachs collected was too low for VI and IR comparisons. All of the 202 full stomach contents were composed by a greenishblack mixture of sediment and organic matter.

\subsection{Stable isotope ratios of stomach contents and muscle tissue}

Food sources directly sorted from stomach contents had the following signatures: nematodes: $\delta^{13} \mathrm{C}:-15.9 \%, \delta^{15} \mathrm{~N}: 11.7 \%$; annelids: $\delta^{13} \mathrm{C}:-15.3 \%, \delta^{15} \mathrm{~N}: 12.2 \%$; plant detritus: $\delta^{13} \mathrm{C}:-15.6 \%$, $\delta^{15} \mathrm{~N}$ : 9.4\% (Fig. 3 and 4). Values reported in Riera et al. (1999) presented lower $\delta^{15} \mathrm{~N}$, particularly those of nematodes and annelids with a difference of up to $4.2 \%$. The mean isotope ratios for microphytobenthos from Richard (Unpublished results) and Riera et al. (1999) ranged from -16.6 to $-14.4 \%$ for $\delta^{13} \mathrm{C}$ and from 4.5 to $6.3 \%$ for $\delta^{15} \mathrm{~N}$.

Isotope ratios of $\mathrm{G} 0$ ranged from -22.1 to $-18.4 \%$ for $\delta^{13} \mathrm{C}$ and from 8.0 to $12.8 \%$ for $\delta^{15} \mathrm{~N}$ (Fig. 3) and show a very large increase in $\delta^{13} \mathrm{C}$ and $\delta^{15} \mathrm{~N}$ values between individuals of 20 to 
$30 \mathrm{~mm}$ in length. Mullets longer than $30 \mathrm{~mm}$ in length presented $\delta^{13} \mathrm{C}$ and $\delta^{15} \mathrm{~N}$ values approaching those of G1.

In spring, $\delta^{13} \mathrm{C}$ and $\delta^{15} \mathrm{~N}$ values of $L$. ramada and L. aurata $\mathrm{G} 1$ ranged from -17.4 to $12.7 \%$ for $\delta^{13} \mathrm{C}$ and from 12.4 to $18.7 \%$ for $\delta^{15} \mathrm{~N}$ (Fig. 3); they were not significantly different between species (Wilcoxon-tests, $\delta^{13} \mathrm{C}: \mathrm{p}=0.156, \delta^{15} \mathrm{~N}: \mathrm{p}=0.734$ ). $\delta^{13} \mathrm{C}$ and $\delta^{15} \mathrm{~N}$ values of $\mathrm{G} 1$ individuals were, on average, higher than those of G0 individuals (Wilcoxontests, $\left.\delta^{13} \mathrm{C}: \mathrm{p}<0.001, \delta^{15} \mathrm{~N}: \mathrm{p}<0.001\right)$. Mean differences in $\delta^{15} \mathrm{~N}$ between muscle and stomach content signatures were $2.7 \%$ for both species (Table 3 ). Stomach content signatures were similar between both species (Wilcoxon tests, $\delta^{13} \mathrm{C}: \mathrm{p}=0.607, \delta^{15} \mathrm{~N}: \mathrm{p}=1.000$ ), ranging from -24.2 to $-14.5 \%$ for $\delta^{13} \mathrm{C}$ and from 9.6 to $14.1 \%$ for $\delta^{15} \mathrm{~N}$ (Fig. 4). Range of stomach content $\delta^{13} \mathrm{C}$ was wider and more depleted than the one of muscle tissue; nevertheless most of stomach content $\delta^{13} \mathrm{C}$ ranged from -18.0 to $-14.0 \%$.

Signatures of G2 muscle tissue were highly variable in spring, particularly for $\delta^{13} \mathrm{C}$, with values ranging from -25.4 to $-10.5 \%$, and not significantly different between species (Wilcoxon tests, $\delta^{13} \mathrm{C}: \mathrm{p}=0.373, \delta^{15} \mathrm{~N}: \mathrm{p}=1.000$ ). $\delta^{15} \mathrm{~N}$ values (both species taken together) were similar to the ones of $\mathrm{G} 1$ individuals (Wilcoxon test, $\mathrm{p}=0.905$ ) whereas $\mathrm{G} 2 \delta^{13} \mathrm{C}$ values were much lower than $\mathrm{G} 1 \delta^{13} \mathrm{C}$ (Wilcoxon test, $\mathrm{p}=0.001$ ) (Table 3). The few stomach content samples from $L$ ramada $\mathrm{G} 2$ individuals showed stable isotope ratios similar to those of $L$. ramada $\mathrm{G} 1$ (Wilcoxon-tests, $\delta^{13} \mathrm{C}: \mathrm{p}=0.582, \delta^{15} \mathrm{~N}: \mathrm{p}=0.727$ ). Differences between muscle and stomach content signatures were high, particularly for $\delta^{15} \mathrm{~N}(3.2 \%$ for $L$. ramada). Only one stomach content from L. aurata was sampled in spring. There were no G2 individuals in the summer sample.

$\delta^{13} \mathrm{C}$ of G3+ muscle tissues were similar to those of $\mathrm{G} 2$ individuals but lower than those of G1 (Wilcoxon tests, G2: $\mathrm{p}=0.150, \mathrm{G} 1: \mathrm{p}=0.001$ ). $\delta^{15} \mathrm{~N}$ of G3+ muscle tissues were similar to those of $\mathrm{G} 2$ and $\mathrm{G} 1$ individuals (Wilcoxon tests, $\mathrm{G} 2 \mathrm{p} \mathrm{p}=0.632, \mathrm{G} 1$ : $\mathrm{p}=0.507$ ). Almost all values ranged from -17.7 to $-12.9 \%$ for $\delta^{13} \mathrm{C}$ and from 9.7 to $15.1 \%$ for $\delta^{15} \mathrm{~N}$. Only three individuals were outside of this range, with lower $\delta^{13} \mathrm{C}$ values (-19.3, -24.7 and -26.1\%) and very high $\delta^{15} \mathrm{~N}$ values (17.2 and 18.0\%) for two of them (Fig. 3). G3+ stomach contents showed a very large range of signatures $\left(\delta^{13} \mathrm{C}:-22.6\right.$ to $-15.3 \% ; \delta^{15} \mathrm{~N}$ : 9.3 to $\left.13.5 \%\right)$. No differences were observed between $\mathrm{G} 3+$ and $\mathrm{G} 1$ age groups (Wilcoxon-tests, $\delta^{13} \mathrm{C}: \mathrm{p}=0.063$, $\left.\delta^{15} \mathrm{~N}: \mathrm{p}=0.568\right)$. Differences between $\mathrm{G} 3+$ muscle tissue and stomach contents were on average $0.4 \%$ for $\delta^{13} \mathrm{C}$ and $2.7 \%$ for $\delta^{15} \mathrm{~N}$ (Table 3). 


\section{DISCUSSION}

4.1 Which groups of mullet colonize salt marsh creeks?

Only two species of mullet, Liza ramada and Liza aurata, colonize the salt marsh. No specimens of Chelon labrosus were caught during our sampling, such as in a previous study in the same site (Parlier et al., 2006). C. labrosus has however been observed in similar embayments along European Atlantic coasts (Labourg et al., 1985).

G0 individuals, not identified to the species level during this study, were probably specimens of both species (Parlier et al., 2006). The large increase in G0 densities that occurred between March and April reflects the coastal recruitment of these species (Lam Hoï, 1969; Hickling, 1970; Labourg et al., 1985). The G0 age group was the most frequent age group of the mullet population. However, due to very low individual biomass, the G0 group only represented a very small proportion of the total biomass, which was largely dominated by G3+. High densities of the G1 age group in both L. ramada and L. aurata were also observed, but very few $\mathrm{G} 2$ mullets were observed. This population structure is similar to that observed by Parlier et al. (2006) in the same bay and of Laffaille et al. $(2000,2002)$ in the Mont Saint-Michel Bay in spring.

This pattern of population structure may have several explanations. First, mullets are known to be highly euryhaline at the G0 and G1 stages of development (Lam Hoï, 1969; Lasserre and Gallis, 1975; Shusmin, 1990). Thus, these individuals were able to withstand salinity variations that occurred in the salt marsh, particularly in spring. Second, G0 and G1 migration into creeks is probably related to the typical high tidal currents in Aiguillon Bay (SHOM, 2001). These currents may have facilitated the migration of these age groups in particular (Dame and Allen, 1996). This hypothesis is strengthened by the observation that the catches of G0 and G1 mullets in the creek were the greatest during the highest tidal current periods, at mid ebb tide.

The absence of $L$. aurata adults (G3+) is probably linked to the relatively low salinities sometimes observed in salt marsh creeks. Adults from this species are known to tolerate only very short periods of low salinity (Lam Hoï, 1969; Keith and Allardi, 2001; Gautier and Hussenot, 2005; Cardona, 2006). On the contrary, L. ramada adults are highly euryhaline, well-known for their migrations into freshwater habitats (Keith and Allardi, 2001), and are thus able to stay in salt marsh creeks during these low salinity periods. The colonization of $L$. ramada adults in these creeks can be considered opportunistic and probably related to their high dietary demand. Mullets show an increase of feeding activity in spring (Hickling, 1970; 
Odum, 1970; Bruslé, 1981) that may be needed to improve overall condition after winter spawning.

Among the four age groups of mullets present in coastal areas, only some of them regularly colonized the salt marsh creeks of Aiguillon Bay in spring: G0, L. ramada and $L$. aurata $\mathrm{G} 1$ and L. ramada $\mathrm{G} 3+$. These observations support the view that this bay is an important habitat for juvenile fish, as are other European salt marshes (Mathieson et al., 2000; Cattrijsse and Hampel, 2006).

\subsection{Stable isotope ratios of food sources}

$\delta^{13} \mathrm{C}$ values of food sources collected in this work are generally in the range of those of previous studies carried out in the Aiguillon bay (Richard, unpublished results; Riera et al., 1999). Three groups are clearly distinguished: 1 . food sources originating from neritic waters, i.e. suspended particulate organic matter (SPOM) and phytoplankton (with $\delta^{13} \mathrm{C}$ values ranging from -23 to $-20 \%$ ), $2 .{ }^{13} \mathrm{C}$-enriched salt marsh sources, i.e. microphytobenthos and $\mathrm{C} 4$ halophyte plants, such as Spartina maritima (with $\delta^{13} \mathrm{C}$ from -17 to $-12 \%$ ), and $3 .{ }^{13} \mathrm{C}$ depleted salt marsh sources, i.e. C3 halophyte plants, such as Plantago maritima (with $\delta^{13} \mathrm{C}$ lower than $-24 \%$ ). Sediment surface organic matter (SSOM) $\delta^{13} \mathrm{C}$ value $(-20.6 \%$ : Riera et al., 1999) indicates a mixing of depleted (C3) and enriched (C4) salt marsh plant detritus and of microphytobenthos.

Some of these primary producers are not ingested as fresh matter, but as partially degraded matter that may have different isotopic values. Plant detritus sampled in stomach contents had lower $\delta^{13} \mathrm{C}$ values than fresh plant material characterized in previous studies, likely because degraded material is mainly composed of less labile compounds, particularly lignin which is known to have lower $\delta^{13} \mathrm{C}$ than fresh material (Benner et al., 1987). High $\delta^{15} \mathrm{~N}$ values observed in plant detritus were probably related to bacterial film on detritus surfaces, which increases ${ }^{15} \mathrm{~N}$ concentration due to trophic isotopic fractionation (Dijkstra et al., 2008). A similar trend has been observed between fresh and detrital material of $S$. maritima (Riera et al., 1999).

Nematodes and annelids sampled from stomach contents during this study and nematodes from Riera et al. (1999) had $\delta^{13} \mathrm{C}$ values in the range of those of microphytobenthos and $\mathrm{C} 4$ plant detritus, suggesting that these consumers exploit these salt marsh resources. However, nematodes and annelids from stomach contents showed relatively high $\delta^{15} \mathrm{~N}$ values compared with values from Riera et al. (1999), with a difference of $4.2 \%$ for nematodes. This discrepancy suggests that ingested nematodes may not be representative of the in situ 
population. A selection of prey occurs in fact when mullets forage in the superficial sediment layer because they use gill-rakers and taste buds to select the most appetizing food items (Bruslé, 1981).

\subsection{Differential role of the salt marsh as a feeding ground for mullet groups}

The absence of increase of DTW/TW ratios for G0 between flood tide and ebb tide showed that G0 individuals probably feed continuously (Albertini-Berhaut, 1974), within and outside the salt marsh creeks. The very few traces of sediment noticed in stomach contents confirmed that these mullets had not yet shifted to a limno-benthophagous diet, excluding SSOM as a food resource. $\delta^{13} \mathrm{C}$ values of muscle tissue, which were intermediate to those of SPOM and phytoplankton, indicated that G0 individuals exploit food resources from neritic waters. The orange coloration of stomach content suggested that their diet was based on crustaceans, probably zooplankton, which was confirmed by the observation of five stomach content samples that showed zooplankton fragments (swim appendages, etc.) and small copepods. $\delta^{15} \mathrm{~N}$ values of these mullets corresponded to a mean trophic isotopic fractionation of $2.3 \%$ for each of the two trophic levels from phytoplankton to mullets, via zooplankton, which is in the range of isotopic fractionations generally reported for sources and consumers at the base of the food web (Vander Zanden and Rasmussen, 2001). This confirms the trophic level of the G0 age group and that the diet of this age group is based on zooplankton (Albertini-Berhaut, 1973, 1974; Ceccherelli et al., 1981; Ferrari and Chieregato, 1981). So G0 individuals do not depend on salt marsh food resources just after their migration from spawning areas to the salt marsh. These migrations are probably not active due to the weak swimming capacities of G0 compared to the strong tidal currents (SHOM, 2001). Nevertheless, the large ranges of $\delta^{13} \mathrm{C}$ and $\delta^{15} \mathrm{~N}$ suggest that a diet shift occurs in $\mathrm{G} 0$ diet, from planktonic feeding to a limno-benthophagous diet, as previously demonstrated by Albertini-Berhaut $(1973,1974)$ and Ceccherelli et al. (1981). More generally, this trophic shift is also well-known in numerous species of mullets (Bruslé, 1981; Koussoropolis et al., 2010).

The very few G2 individuals observed in salt marsh creeks and the absence of differences for IR between flow and ebb tides demonstrated that these areas are not preferential feeding grounds for these fish, as also shown by Laffaille et al. (2000). The larger range of $\delta^{13} \mathrm{C}$ values in muscle tissue confirms that these mullets have a large range of trophic behaviors and/or habitats, probably from terrestrial to oceanic areas. However, the few samples collected do not allow a clear understanding of G2 diet. 
On the contrary, salt marsh resources are heavily used by G1 and G3 individuals. For G1 individuals, the strong increase in their IR when they were present in the salt marsh creeks indicates that they were feeding there. The quantity of food ingested before mullets migrate to the creeks is extremely low, demonstrating that salt marsh creeks are preferential feeding grounds for these mullets when they colonize these areas.

As for G1, the strong increase of $L$. ramada $\mathrm{G} 3+$ IRs between flood and ebb tides showed that these mullets migrate to salt marsh creeks for feeding purposes during high tides, as in Mont Saint-Michel Bay (Laffaille et al., 1998; Laffaille et al., 2002). However, contrary to G1, mean IR values at flood tide showed that numerous G3 individuals enter the creek with a partially full stomach. Retention time of food in the digestive tract of mullets ranges from 2 to $6 \mathrm{~h}$ (Bruslé, 1981), leading to the conclusion that adult mullets feed on the adjacent mudflat before they migrate into salt marsh creeks. The same behavior has been observed in Mont Saint-Michel salt marsh creeks (Laffaille et al., 2002). In this bay, mean observed IR values (close to 3\% in March and to 7\% in April) are clearly higher than those observed in spring in Aiguillon Bay (only 1.4\%), indicating that mullets feed less intensively on Aiguillon Bay mudflats before migrating to the salt marsh.

Muscle and stomach content $\delta^{13} \mathrm{C}$ of G1 and G3+ individuals demonstrated the salt marsh origin of food resources (meiofauna, halophyte plant detritus, microphytobenthos...). The large quantities of sediment in stomach content confirmed the limno-benthophagous diet of G1 (L. ramada and L. aurata) and of G3+ (L. ramada), as in many other ecosystems (Hickling, 1970; Albertini-Berhaut, 1974; Bruslé, 1981; Ferrari and Chieragato, 1981; Almeida et al., 1993; Shapiro, 1998; Laffaille et al, 2002) and such as many other species (Bruslé, 1981; Koussoropolis et al., 2010). The numerous foraging traces on the sediment at ebb tides corroborated these observations (Laffaille et al,. 2002). The large range of G1 and $\mathrm{G} 3+$ stomach content $\delta^{13} \mathrm{C}$ showed that they contained a mixture of ${ }^{13} \mathrm{C}$-enriched salt marsh sources and of ${ }^{13} \mathrm{C}$-depleted salt marsh plants, such as Aster tripolium, Halimione portulacoides or Plantago maritima which grow on this area (Verger, 2005) and generally have low $\delta^{13} \mathrm{C}$ values (Riera et al., 1999). Nevertheless the range of $\mathrm{G} 1$ and $\mathrm{G} 3+$ muscle, narrower and more enriched than these of stomach content, demonstrated that $\mathrm{C} 3$ halophyte plant material, even if it is ingested, is thus hardly assimilated by mullets. G3+ showed sometimes some variations of individual behavior. In spring, two mullets showed very low $\delta^{13} \mathrm{C}$ values (-24.7 and $-26.1 \%$ ). These $\delta^{13} \mathrm{C}$ values, similar to typical terrestrial sources, indicated that these mullets probably spent the winter in river waters and have not carried out their catadromous migration for breeding. One other individual showed $\delta^{13} \mathrm{C}$ values typical of 
oceanic food resources, indicating that this individual was sampled probably just after its migration to coastal areas after the spawning season.

Thus G1 and G3+ clearly colonize intertidal salt marsh creeks for the purpose of feeding, as previously demonstrated for mullets in other salt marshes or even in rivers (Lam Hoï, 1969; Sauriau, 1990; Keith and Allardi, 2001; Laffaille et al., 2002; Almeida, 2003; Koussoropolis et al., 2010) and as for numerous other nektonic species (Deegan et al., 1990; Laffaille et al., 2001; Lefeuvre et al., 1999). Salt marshes are in fact well known for their role as feeding areas (Kneib, 1997). However, the macrotidal range of the Aiguillon and Mont Saint Michel Bays salt marshes gives them strong particularities because fishes migrate daily to these feeding areas (Lefeuvre et al., 1999). Colonizing salt marsh creeks is riskier for mullets (stranding, bird predation for G1) and represents higher energy loss than feeding on bare mudflats (Wolff et al., 1981; Gibson, 2003), where they are not likely to be food-limited. These risks and energetic costs of migrations may be counteracted by a maximization of G1 and G3+ food intake in salt marsh creeks (Gibson, 2003).

\subsection{Mullet trophic level}

High $\delta^{15} \mathrm{~N}$ values of muscles indicated a high trophic level, at least secondary, for G1 and $\mathrm{G} 3+$ individuals. As for the G0 age group, there was a good relationship between $\delta^{15} \mathrm{~N}$ values of muscle tissue and stomach contents, with a mean trophic fractionation ranging from 2.7. This value matches Vander Zanden and Rasmussen's (2001) observations for high-level consumers. Stomach content signatures, close to those of primary consumers (nematodes, annelids), highlight that diet of G1 and G3+ individuals were partially based on these prey, which were observed in large quantities in stomach contents along with benthic diatoms and detrital matter. The high muscle $\delta^{15} \mathrm{~N}$ values indicate that among the large diversity of food sources they ingest, from primary producers to animals, mullets incorporate more $\mathrm{N}$ from the most ${ }^{15} \mathrm{~N}$-enriched food sources (e. g. meiofauna, small macrofauna). This can be due to a better assimilation of animal prey than of primary producers (e. g. C3 and C4 salt marsh plants) which have lower nutritional quality, and thus lower digestibility (Cebrián, 1999). It can also be due to the higher protein content of muscle tissue, which $\mathrm{N}$ isotope signature reflects thus more the isotope composition of animal preys than of plants, much less proteic. Primary producers have a high content of carbohydrates, mainly and readily used for animal metabolism, the fish muscle $\delta^{13} \mathrm{C}$ may therefore not completely reflect their actual assimilation. 
Our study gives information on assimilated food sources and thus on more profitable salt marsh resources for mullets. It well complete works previously made on stomach contents (Almeida et al., 1993; Laffaille et al., 2002), which determined the food sources ingested by mullets, and on which animal preys have been regularly observed in stomach contents (Ezzat, 1963; Lasserre et al., 1976; Laffaille et al., 1998), without necessarily determining their role in mullet resources. Although detritus and benthic diatoms constitute a large proportion of stomach contents, stable isotopes demonstrate that animal prey represent a very high contribution of resources incorporated into fish tissues when they migrate in the salt marshes.

High $\delta^{15} \mathrm{~N}$ values have already been observed in mullets from a bare mudflat (Richard, unpublished results), but are slightly lower (13.2 $\pm 0.7 \%$ on average) than those observed in this study. Bacterivorous nematodes, that are ${ }^{15} \mathrm{~N}$-enriched relative to herbivorous species (Rzeznik-Orignac et al., 2008), are likely to be present in higher proportions than herbivorous ones when detrital organic matter and thus bacteria are very abundant, as in salt marshes (Moens et al., 1999). This difference is also probably due to a larger part of meiofauna in the diet of mullets feeding in creeks. Nematode abundance can be several times higher in salt marshes covered with halophytic plants ( Heip et al., 1985; Giere, 1993) than in bare mudflats (Rzeznik-Orignac et al., 2003). The higher availability of more protein-rich food sources, such as meiofauna in the salt marsh creeks may explain why mullets migrate in the salt marsh creeks, when they can find enough food resources on the bare mudflat they pass through. For G3+ individuals, this feeding behavior may be induced by the strong increase in their nutritional requirements since they have a poor overall condition after the spawning period.

\section{CONCLUSION}

Five groups of mullets migrate to salt marsh creeks for feeding purposes: $L$. ramada and L. aurata $\mathrm{G} 0$ after their trophic shift, L. ramada and L. aurata $\mathrm{G} 1$ and $L$. ramada adults. All fishes from these five groups are well known for their euryhaline behavior (Keith and Allardi, 2001; Gautier and Hussenot, 2005; Cardona, 2006). These migrations for purpose of feeding, already well known in adults, are also realized by young-of-the-year, after their trophic shift, and by G1 but not by G2. During these periods of salt marsh colonization, mullets have a limno-benthophagous diet behavior and a diet mostly based on animal prey, particularly meiofauna, positioning mullets at a high trophic level. This assertion contrasts with the general knowledge on mullets, which are generally considered as primary consumers (Bruslé, 1981; Almeida et al., 1993; Shapiro, 1998; Laffaille et al., 2002). 


\section{ACKNOWLEDGEMENTS}

This study was part of B. Lebreton's Master's thesis. B. Lebreton is grateful to O. Herlory for his useful advice, to P.G. Sauriau and J. Hussenot for their help during bibliographic research and to L. Hutchison for language corrections. Authors thank P. Pineau, D. Leguay, F. Mornet, M. Bréret, D. Fichet, G. Radenac, J.-M. Guarini, E. Durieux, P.-Y. Pascal, K. Faucher, E. Marquis, P. Ory, S. Millot, E. Réveillac, M. Cannas, S. Jane-d'Amour, P. Pinet, N. Judde, B. Remy-Zephir, P. Cuzange, J. Don, F. Albert for their invaluable help during fish sampling, as well as the team of the 'Réserve naturelle nationale de la baie de l'Aiguillon', particularly F. Meunier.

\section{LITERATURE CITED}

Albertini-Berhaut, J., 1973. Biologie des stades juvéniles de Téléostéens Mugilidae Mugil auratus Risso 1810, Mugil capito Cuvier 1829 et Mugil saliens Risso 1810. I : Régime alimentaire. Aquaculture 2, 251-266.

Albertini-Berhaut, J., 1974. Biologie des stades juvéniles de Téléostéens Mugilidae Mugil auratus Risso 1810, Mugil capito Cuvier 1829 et Mugil saliens Risso 1810. II : Modifications du régime alimentaire en relation avec la taille. Aquaculture 4, 13-27. Almeida, P. R., Moreira, F., Costa, J. L., Assis, C. A., Costa, M. J., 1993. The feeding strategies of Liza ramada (Risso, 1826) in fresh and brackish water in the River Tagus, Portugal. Journal of Fish Biology 42, 95-107.

Benner, R., Fogel, M. L., Sprague, E. K., Hodson, R. E., 1987. Depletion of ${ }^{13} \mathrm{C}$ in lignin and its implication for stable carbon isotope studies. Nature 329, 708-710.

Bouchard, V., Lefeuvre, J. C., 2000. Primary production and macro-detritus dynamics in a European salt marsh: carbon and nitrogen budgets. Aquatic Botany 67, 23-42.

Bruslé, J., 1981. Food and feeding in grey mullet. In: Oren, O. H. (Ed.), Aquaculture of the Grey Mullet. Cambridge Univ. Press, Cambridge, pp. 185-217.

Cambrony, M., 1984. Identification et périodicité du recrutement des juvéniles de Mugilidae dans les étangs littoraux du Languedoc-Roussillon. Vie et Milieu 34, 221-227.

Cardona, L., 1995. Microalgae selection by mullets (Mugil cephalus and Liza ramada) in Israeli semi-intensive fish ponds. The Israeli Journal of Aquaculture 48, 165-173.

Cardona, L., 2006. Habitat selection by grey mullets (Osteichthyes: Mugilidae) in Mediterranean estuaries: the role of salinity. Scientia Marina 70, 443-455. 
Cattrijsse, A., Hampel, H., 2006. European intertidal marshes: a review of their habitat functioning and value for aquatic organisms. Marine Ecology Progress Series 324, 293-307.

Cebrián, J., 1999. Patterns in the fate of production in plant communities. The American Naturalist 154, 449-468.

Ceccherelli, V. U., Ferrari, I., Gaiani, V., 1981. Zooplankton and zoobenthos role in the diet of juvenile stages of different fish species in an embayment of the Po River Delta. Kieler Meersforschungen 5, 259-261.

Dame, R. F., Allen, D. M., 1996. Between estuaries and the sea. Journal of Experimental Marine Biology and Ecology 200, 169-185.

Deegan, L. A., Peterson, B. J., Portier, R., 1990. Stable isotopes and cellulase activity as evidence for detritus as a food source for juvenile gulf Menhaden. Estuaries 13, 1419.

Dijkstra, P., LaViolette, C. M., Coyle, J. S., Doucett, R. R., Schwartz, E., Hart, S. C., Hungate, B. A., 2008. ${ }^{15} \mathrm{~N}$ enrichment as an integrator of the effects of $\mathrm{C}$ and $\mathrm{N}$ on microbial metabolism and ecosystem function. Ecology Letters 11, 389-397.

Ezzat, A., 1963. Contribution à l'étude de la biologie des Mugilidae dans la région de l'étang de Berre et de Port de Bouc. Recueil des Travaux de la Station Marine d'Endoume $31,187-200$.

Farrugio, H., 1977. Clés commentées pour la détermination des adultes et des alevins de Mugilidae de Tunisie. Cybium 2, 57-73.

Ferrari, I., Chieregato, A. R., 1981. Feeding habits of juvenile stages of Sparus auratus L., Dicentrarchus labrax L. and Mugilidae in a brackish embayement of the Po river delta. Aquaculture 25, 243-257.

Fry, B., 2006. Stable Isotope Ecology. Springer, New York, 308 pp.

Gautier, D., Hussenot, J., 2005. Les Mulets des Mers d'Europe : Synthèse des Connaissances sur les Bases Biologiques et les Techniques d'Aquaculture. Ifremer, Plouzané, 119 pp.

Gibson, R. N., 2003. Go with the flow: tidal migration in marine animals. Hydrobiologia 503, 153-161.

Giere, O., 1993. Meiobenthology. The Microscopic Fauna in Aquatic Sediments. SpringerVerlag, Berlin, 328 pp.

Heip, C., Vincx, M., Vranken, G., 1985. The ecology of marine nematodes. Oceanography and Marine Biology. An Annual Review 23, 399-489. 
Hickling, C. F., 1970. A contribution to the natural history of the English grey mullets (Pisces, Mugilidae). Journal of the Marine Biological Association of the United Kingdom 50, 609-633.

Keith, P., Allardi, J., 2001. Atlas des Poissons d'Eau Douce de France. Muséum National d'Histoire Naturelle, Paris, 387 pp.

Kneib, R. T., 1997. The role of tidal marshes in the ecology of estuarine nekton. Oceanography and Marine Biology. An Annual Review 35, 163-220.

Koussoropolis, A.-M., Bec, A., Perga, M.-E., Koutrakis, E., Desvilettes, C., Bourdier, G., 2010. Nutritional importance of minor dietary sources for leaping grey mullet Liza saliens (Mugilidae) during settlement: insights from fatty acid $\delta^{13} \mathrm{C}$ analysis. Marine Ecology Progress Series 404, 207-217.

Labourg, P.-J., Clus, C., Lasserre, P., 1985. Résultats préliminaires sur la distribution des juvéniles de poissons dans un marais maritime du Bassin d'Arcachon. Oceanologica Acta 8, 331-341.

Laffaille, P., Brosse, S., Feunteun, E., Baisez, A., Lefeuvre, J. C., 1998. Role of fish communities in particulate organic matter fluxes between salt marshes and coastal marine waters in the Mont Saint-Michel Bay. Hydrobiologia 373/374, 121-133.

Laffaille, P., Feunteun, E., Lefebvre, C., Radureau, A., Sagan, G., Lefeuvre, J. C., 2002. Can thin-lipped mullet directly exploit the primary and detritic production of European macrotidal salt marshes? Estuarine, Coastal and Shelf Science 54, 729-736.

Laffaille, P., Feunteun, E., Lefeuvre, J. C., 2000. Composition of fish communities in a European macrotidal salt marsh (the Mont Saint-Michel bay, France). Estuarine, Coastal and Shelf Science 51, 429-438.

Laffaille, P., Lefeuvre, J. C., Schricke, M. T., Feunteun, E., 2001. Feeding ecology of 0-group sea bass, Dicentrarchus labrax, in salt marshes of Mont Saint Michel Bay (France). Estuaries 24, 116-125.

Lam Hoï, T., 1969. Contribution à l'étude de la biologie des Mugilidés (Poissons Téléostéens) des côtes du Massif Armoricain. Travaux de la Faculté des Sciences de Rennes, Série Océanographie Biologique 2, 55-182.

Lasserre, P., Gallis, J. L., 1975. Osmoregulation and differential penetration of two grey mullets, Chelon labrosus (Risso) and Liza ramada (Risso) in estuarine fish ponds. Aquaculture 5, 323-344.

Lasserre, P., Renaud-Mornand, J., Castel, J., 1976. Metabolic activities of meiofaunal communities in a semi-enclosed lagoon: possibilities of trophic competition between 
meiofauna and mugilid fish. In: Persoone, G., Jaspers, E. (Eds.), 10th European Symposium on Marine Biology. 2. Population dynamics of marine organisms in relation with nutrient cycling in shallow waters. Universa Press, Wetteren, Belgium, pp. 393-414.

Le Dantec, J., 1955. Quelques observations sur la biologie des muges des réservoirs de Certes, à Audence. Revue des Travaux de l'Institut Scientifique des Pêches Maritimes 19, 93-116.

Lefeuvre, J. C., Laffaille, P., Feunteun, E., 1999. Do fish communities function as biotic vectors of organic matter between salt marshes and marine coastal waters? Aquatic Ecology 33, 293-299.

Mann, K. H., 1988. Production and use of detritus in various freshwater, estuarine, and coastal marine ecosystems. Limnology and Oceanography 33, 910-930.

Mathieson, S., Cattrijsse, A., Costa, M. J., Drake, P., Elliott, M., Gardner, J., Marchand, J., 2000. Fish assemblages of European tidal marshes: a comparison based on species, families and functional guilds. Marine Ecology Progress Series 204, 225-242.

Moens, T., Verbeeck, L., de Maeyer, A., Swings, J., Vincx, M., 1999. Selective attraction of marine bacterivorous nematodes to their bacterial food. Marine Ecology Progress Series 176, 165-178.

Odum, W. E., 1968. The ecological significance of fine particule selection by the striped mullet Mugil cephalus. Limnology and Oceanography 13, 92-98.

Odum, W. E., 1970. Utilization of the direct grazing and plant detritus food chains by the striped mullet Mugil cephalus. In: Steele, J. H. (Ed.), Marine Food Chains. Univ. of California Press, Berkeley, pp. 222-240.

Parlier, E. P., Albert, F., Cuzange, P.-A., Don, J., Feunteun, E., 2006. Impact of vegetation structure dynamics and usage on the nursery function of West European tidal saltmarshes. Cahiers de Biologie Marine 47, 47-62.

Pinnegar, J. K., Polunin, N. V. C., 1999. Differential fractionation of $\delta^{13} \mathrm{C}$ and $\delta^{15} \mathrm{~N}$ among fish tissues: implications for the study of trophic interactions. Functional Ecology $13,225-231$.

Quan, W., Fu, C., Jin, B., Luo, Y., Li, B., Chen, J., Wu, J., 2007. Tidal marshes as energy sources for commercially important nektonic organisms: stable isotope analysis. Marine Ecology Progress Series 352, 89-99.

Riera, P., Stal, L. J., Nieuwenhuize, J., Richard, P., Blanchard, G. F., Gentil, F., 1999. Determination of food sources for benthic invertebrates in a salt marsh (Aiguillon 
Bay, France) by carbon and nitrogen stable isotopes: importance of locally produced sources. Marine Ecology Progress Series 187, 301-307.

Rzeznik-Orignac, J., Boucher, G., Fichet, D., Richard, P., 2008. Stable isotope analysis of food source and trophic position of intertidal nematodes and copepods. Marine Ecology Progress Series 359, 145-150.

Rzeznik-Orignac, J., Fichet, D., Boucher, G., 2003. Spatio-temporal structure of the nematode assemblages of the Brouage mudflat (Marennes Oléron, France). Estuarine, Coastal and Shelf Science 58, 77-88.

Shapiro, J., 1998. Food of the thin-lipped grey mullet (Liza ramada) in lake Kinneret, Israel. The Israeli Journal of Aquaculture - Bamidgeh 50, 3-11.

SHOM, 2001. Courants de marée de la côte ouest de France : de Saint Nazaire à Royan. Service Hydrographique et Océanographique de la Marine, Brest, 72 pp.

Shusmin, A. G., 1990. Effects of change on salinity on survival, oxygen threshold and level of standard metabolism of young of the golden grey mullet (Liza aurata). Journal of Ichthyology 30, 139-145.

Tenore, K. R., 1983. What controls the availability to animals of detritus derived from vascular plants: Organic nitrogen enrichment or caloric availability? Marine Ecology Progress Series 10, 307-309.

Vander Zanden, M. J., Rasmussen, J. B., 2001. Variation in $\delta^{15} \mathrm{~N}$ and $\delta^{13} \mathrm{C}$ trophic fractionation: implications for aquatic food web. Limnology and Oceanography 46, 2061-2066.

Verger, F., 2005. Marais et estuaires du littoral français. Belin, Paris, 335 pp.

Wolff, W. J., Mandos, M. A., Sandee, A. J. J., 1981. Tidal migration of plaice and flounders as a feeding strategy. In: Jones, N. V., Wolff, W.J. (Eds.), Feeding and Survival Strategies of Estuarine Organisms. Marine Science 15. Plenum Press, New York, pp. 159-171. 


\section{FIGURE CAPTIONS}

Fig. 1. Location of the Aiguillon Bay and sampling site.

Fig. 2. Size-frequency distributions and age groups of the two studied mullet species, Liza aurata (fork length $>50 \mathrm{~mm}$ ) and Liza ramada (fork length $>50 \mathrm{~mm}$ ) in spring 2005.

Fig. 3. $\delta^{13} \mathrm{C}$ and $\delta^{15} \mathrm{~N}$ of mullet muscle tissue, potential food sources and prey. For mullet muscle tissues, each point represents one individual. Potential food sources and prey: Ann: annelids, Mpb: microphytobenthos, Nem: nematodes, Phy: phytoplankton, Pma: Plantago maritima, Sma: fresh Spartina maritima, Sma det: detritic S. maritima, SPOM: suspended particulate organic matter, SSOM: surface sediment organic matter, Pla det: plant detritus. Food source data taken from Richard (1998, unpublished results) are italicized, from Richard (2004, unpublished results) underlined, from Riera et al. (1999) are in normal face type, and those from the present study are in bold face type. Plotted G0 points are circled. 
Fig. 4. $\delta^{13} \mathrm{C}$ and $\delta^{15} \mathrm{~N}$ of mullet stomach contents at ebb tide, potential food sources and prey. For mullets, each point represents one individual. Potential food sources and prey: Ann: annelids, Mpb: microphytobenthos, Nem: nematodes, Phy: phytoplankton, Pma: Plantago maritima, Sma: fresh Spartina maritima. Sma det: detritic S. maritima, SPOM: suspended particulate organic matter, SSOM: sediment surface organic matter, Pla det: plant detritus. Food source data taken from Richard (1998, unpublished results) are italicized, from Richard (2004, unpublished results) underlined, from Riera et al. (1999) are in normal face type, and those from the present study are in bold face type. 


\section{TABLES}

Table 1. Fork lengths (FL, mean \pm standard deviation), catch per unit effort by number $\left(\mathrm{CPUE}_{\mathrm{n}}\right.$, mean \pm standard deviation) and by biomass $\left(\mathrm{CPUE}_{\mathrm{m}}\right.$, mean \pm standard deviation) of mullets sampled at ebb tide in spring 2005. Age groups: G0: young-of-the-year, G1: 1 yearold mullets, G2: 2 year-old mullets, G3+: 3 year-old and older mullets.

\begin{tabular}{|c|c|c|c|c|c|c|c|c|}
\hline \multirow{2}{*}{ Species } & \multirow{2}{*}{$\begin{array}{l}\text { Age } \\
\text { group }\end{array}$} & \multirow{2}{*}{$\begin{array}{c}\text { Spring } \\
\text { sampling } \\
\text { week }\end{array}$} & \multirow[b]{2}{*}{$\mathrm{n}$} & \multirow{2}{*}{$\begin{array}{c}\text { Fork } \\
\text { length } \\
\text { mm }\end{array}$} & \multicolumn{2}{|c|}{$\mathrm{CPUE}_{\mathrm{n}}$} & \multicolumn{2}{|c|}{$\mathrm{CPUE}_{\mathrm{m}}$} \\
\hline & & & & & ind. $\min ^{-1}$ & $\begin{array}{l}\text { Mean \% } \\
\text { per week }\end{array}$ & g. $\min ^{-1}$ & $\begin{array}{l}\text { Mean \% } \\
\text { per week }\end{array}$ \\
\hline \multirow[t]{3}{*}{ Liza sp. $(\mathrm{FL}<50 \mathrm{~mm})$} & G0 & 1 & 106 & $21 \pm 1$ & $0.22 \pm 0.39$ & 50.9 & $0.02 \pm 0.02$ & 0.5 \\
\hline & & 2 & 562 & $20 \pm 2$ & $1.12 \pm 1.31$ & 94.5 & $0.09 \pm 0.10$ & 0.7 \\
\hline & & 3 & 890 & $20 \pm 2$ & $1.49 \pm 2.76$ & 96.9 & $0.10 \pm 0.19$ & 1.0 \\
\hline \multirow[t]{6}{*}{ L. $\operatorname{aurata}(\mathrm{FL}>50 \mathrm{~mm})$} & G1 & 1 & 34 & $80 \pm 15$ & $0.07 \pm 0.09$ & 17.4 & $0.42 \pm 0.50$ & 14.0 \\
\hline & & 2 & 10 & $81 \pm 20$ & $0.01 \pm 0.01$ & 0.8 & $0.04 \pm 0.04$ & 0.3 \\
\hline & & 3 & 13 & $78 \pm 13$ & $0.02 \pm 0.02$ & 1.0 & $0.06 \pm 0.08$ & 0.6 \\
\hline & $\mathrm{G} 2$ & 1 & 1 & 164 & $<0.01 \pm 0.01$ & 0.7 & $0.18 \pm 0.36$ & 6.0 \\
\hline & & 2 & 1 & 150 & $<0.01 \pm<0.01$ & 0.2 & $0.10 \pm 0.22$ & 0.7 \\
\hline & & 3 & 0 & - & 0 & 0 & 0 & 0 \\
\hline \multirow[t]{9}{*}{ L. $\operatorname{ramada}(\mathrm{FL}>50 \mathrm{~mm})$} & G1 & 1 & 63 & $77 \pm 14$ & $0.13 \pm 0.09$ & 29.7 & $0.57 \pm 0.45$ & 18.9 \\
\hline & & 2 & 21 & $77 \pm 13$ & $0.04 \pm 0.02$ & 3.4 & $0.23 \pm 0.04$ & 1.8 \\
\hline & & 3 & 11 & $81 \pm 18$ & $0.02 \pm 0.03$ & 1.0 & $0.11 \pm 0.19$ & 1.0 \\
\hline & $\mathrm{G} 2$ & 1 & 1 & 195 & $<0.01 \pm<0.01$ & 0.4 & $0.14 \pm 0.27$ & 4.5 \\
\hline & & 2 & 0 & - & 0 & 0 & 0 & 0 \\
\hline & & 3 & 2 & $173 \pm 21$ & $<0.01 \pm 0.01$ & 0.3 & $0.20 \pm 0.46$ & 1.9 \\
\hline & G3+ & 1 & 2 & $335 \pm 56$ & $<0.01 \pm 0.01$ & 0.9 & $1.70 \pm 3.40$ & 56.2 \\
\hline & & 2 & 15 & $401 \pm 27$ & $0.01 \pm 0.01$ & 1.2 & $12.61 \pm 10.02$ & 96.6 \\
\hline & & 3 & 14 & $391 \pm 40$ & $0.01 \pm 0.01$ & 0.9 & $10.08 \pm 10.75$ & 95.5 \\
\hline
\end{tabular}


Table 2. Comparisons of vacuity indexes (\%) and instantaneous feeding rations (IR, \% mean \pm standard deviation) of Liza aurata and L. ramada at flood tide and at ebb tide in spring 2005. Age groups: G0: Young-of-the-year, G1: 1 year-old mullets, G2: 2 year-old mullets, G3+: 3 year-old and older mullets.

\begin{tabular}{|c|c|c|c|c|c|c|c|c|c|c|c|}
\hline \multirow{2}{*}{$\begin{array}{l}6 \\
7 \\
8 \text { Species } \\
9\end{array}$} & \multirow[b]{2}{*}{$\begin{array}{l}\text { Age } \\
\text { group }\end{array}$} & \multicolumn{3}{|c|}{ Vacuity indexes } & \multicolumn{3}{|c|}{ Instantaneous feeding rations } & \multicolumn{2}{|c|}{ IR values $<1 \%$} & \multicolumn{2}{|c|}{$\mathrm{n}$} \\
\hline & & $\begin{array}{c}\text { Flood } \\
\text { tide }\end{array}$ & $\begin{array}{l}\text { Ebb } \\
\text { tide }\end{array}$ & $\begin{array}{l}\mathrm{Khi}^{2} \\
\text { test }\end{array}$ & $\begin{array}{l}\text { Flood } \\
\text { tide }\end{array}$ & $\begin{array}{l}\text { Ebb } \\
\text { tide }\end{array}$ & $\begin{array}{c}\text { Wilcoxon } \\
\text { test }\end{array}$ & $\begin{array}{c}\text { Flood } \\
\text { tide }\end{array}$ & $\begin{array}{l}\text { Ebb } \\
\text { tide }\end{array}$ & $\begin{array}{c}\text { Flood } \\
\text { tide }\end{array}$ & $\begin{array}{l}\text { Ebb } \\
\text { tide }\end{array}$ \\
\hline & & $\%$ & $\%$ & $\mathrm{p}$ & $\%$ & $\%$ & $\mathrm{p}$ & $\%$ & $\%$ & & \\
\hline aurata & G1 & 34.0 & 27.8 & 0.537 & $0.75 \pm 1.81$ & $2.58 \pm 2.30$ & $<0.001$ & 81 & 36 & 53 & 36 \\
\hline & $\mathrm{G} 2$ & - & - & - & - & - & - & - & - & 2 & 1 \\
\hline ramada & G1 & 32.7 & 13.0 & 0.009 & $0.63 \pm 1.08$ & $3.41 \pm 3.54$ & $<0.001$ & 83 & 30 & 52 & 69 \\
\hline & $\mathrm{G} 2$ & 20.0 & 0.0 & 0.673 & $0.36 \pm 0.33$ & $3.02 \pm 4.73$ & 0.760 & 100 & 67 & 5 & 4 \\
\hline & G3+ & 0.0 & 4.6 & 0.528 & $1.39 \pm 1.06$ & $4.23 \pm 2.90$ & 0.002 & 45 & 14 & 11 & 22 \\
\hline
\end{tabular}


Table 3. $\delta^{13} \mathrm{C}$ and $\delta^{15} \mathrm{~N}$ (mean \pm standard deviation) of muscle tissue and stomach content of mullets in spring 2005 and difference $(\Delta)$ between muscle and stomach content signatures. Number of analyzed samples is shown in parentheses. Age groups: G0: young-of-the-year, G1: 1 year-old mullets, G2: 2 year-old mullets, G3+: 3 year-old and older mullets.

\begin{tabular}{|c|c|c|c|c|c|}
\hline & $\begin{array}{l}\text { Age } \\
\text { group }\end{array}$ & Species & $\begin{array}{c}\text { Muscle tissue } \\
\% \text { o }\end{array}$ & $\begin{array}{c}\text { Stomach contents } \\
\%\end{array}$ & $\begin{array}{l}\Delta \\
\%\end{array}$ \\
\hline \multicolumn{6}{|l|}{$\delta^{13} \mathrm{C}$} \\
\hline & G0 & Liza sp. & $-20.3 \pm 0.9(49)$ & - & - \\
\hline & G1 & L. ramada & $-14.9 \pm 1.3(14)$ & $-16.1 \pm 1.6(16)$ & 1.2 \\
\hline & & L. aurata & $-14.1 \pm 1.0(9)$ & $-17.0 \pm 2.6(15)$ & 2.9 \\
\hline & $\mathrm{G} 2$ & L. ramada & $-17.6 \pm 4.1(9)$ & $-16.2 \pm 1.4(3)$ & 1.4 \\
\hline & & L. aurata & $-20.1 \pm 3.4(3)$ & $-18.0(1)$ & 2.1 \\
\hline & G3+ & L. ramada & $-16.9 \pm 3.3(20)$ & $-17.3 \pm 3.9(13)$ & 0.4 \\
\hline \multicolumn{6}{|l|}{$\delta^{15} \mathrm{~N}$} \\
\hline & G0 & Liza $s p$ & $9.8 \pm 1.2(27)$ & - & - \\
\hline & G1 & L. ramada & $14.1 \pm 1.5(14)$ & $11.4 \pm 1.2(9)$ & 2.7 \\
\hline & & L. aurata & $14.1 \pm 1.3(9)$ & $11.4 \pm 0.5(6)$ & 2.7 \\
\hline & G2 & L. ramada & $13.9 \pm 2.8(9)$ & $10.7 \pm 1.5(2)$ & 3.2 \\
\hline & & L. aurata & $13.7 \pm 2.8$ & $10.9(1)$ & 2.8 \\
\hline & G3+ & L. ramada & $13.8 \pm 2.2(20)$ & $11.1 \pm 1.2(11)$ & 2.7 \\
\hline
\end{tabular}




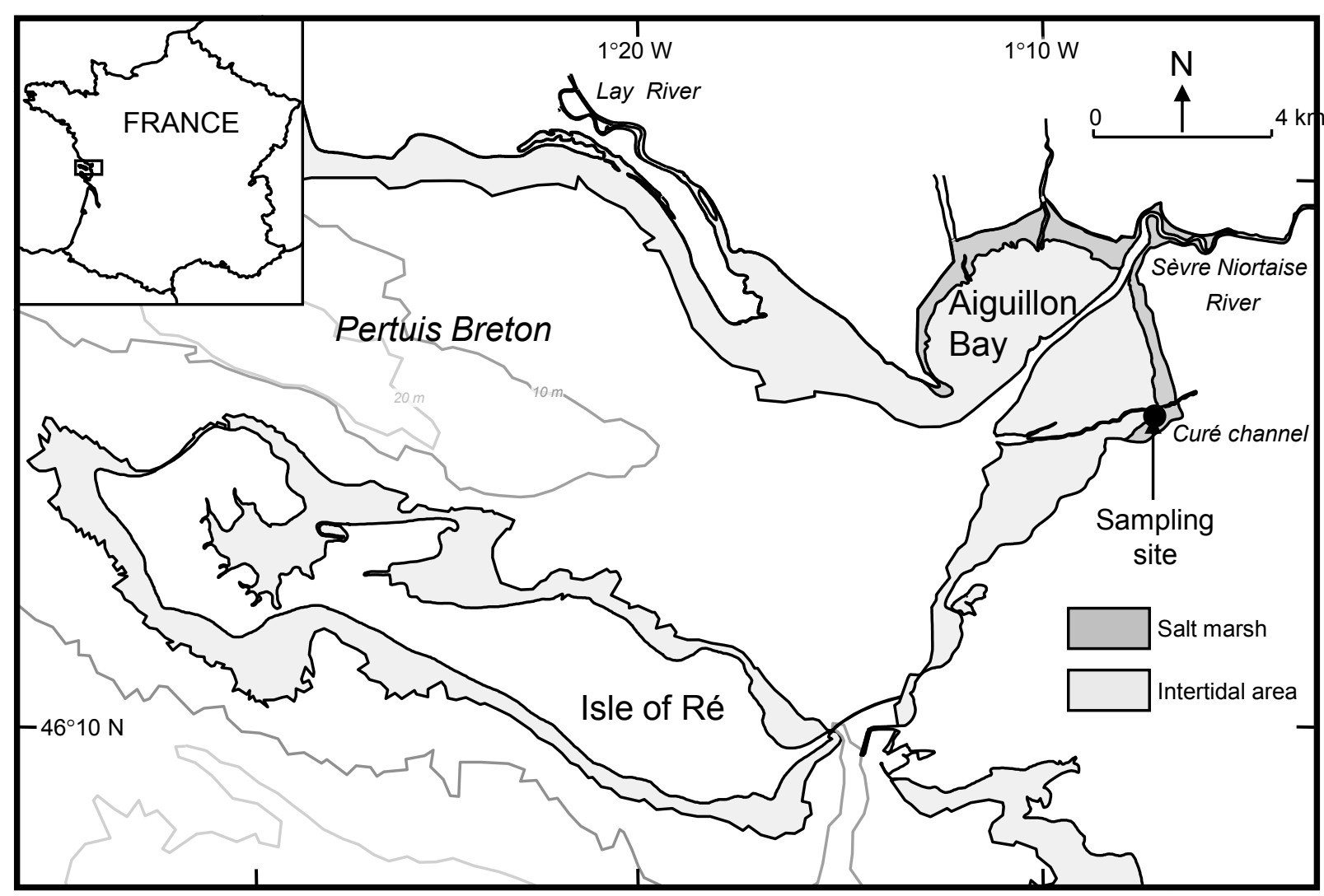


Figure 2

60 ] G0 Both species
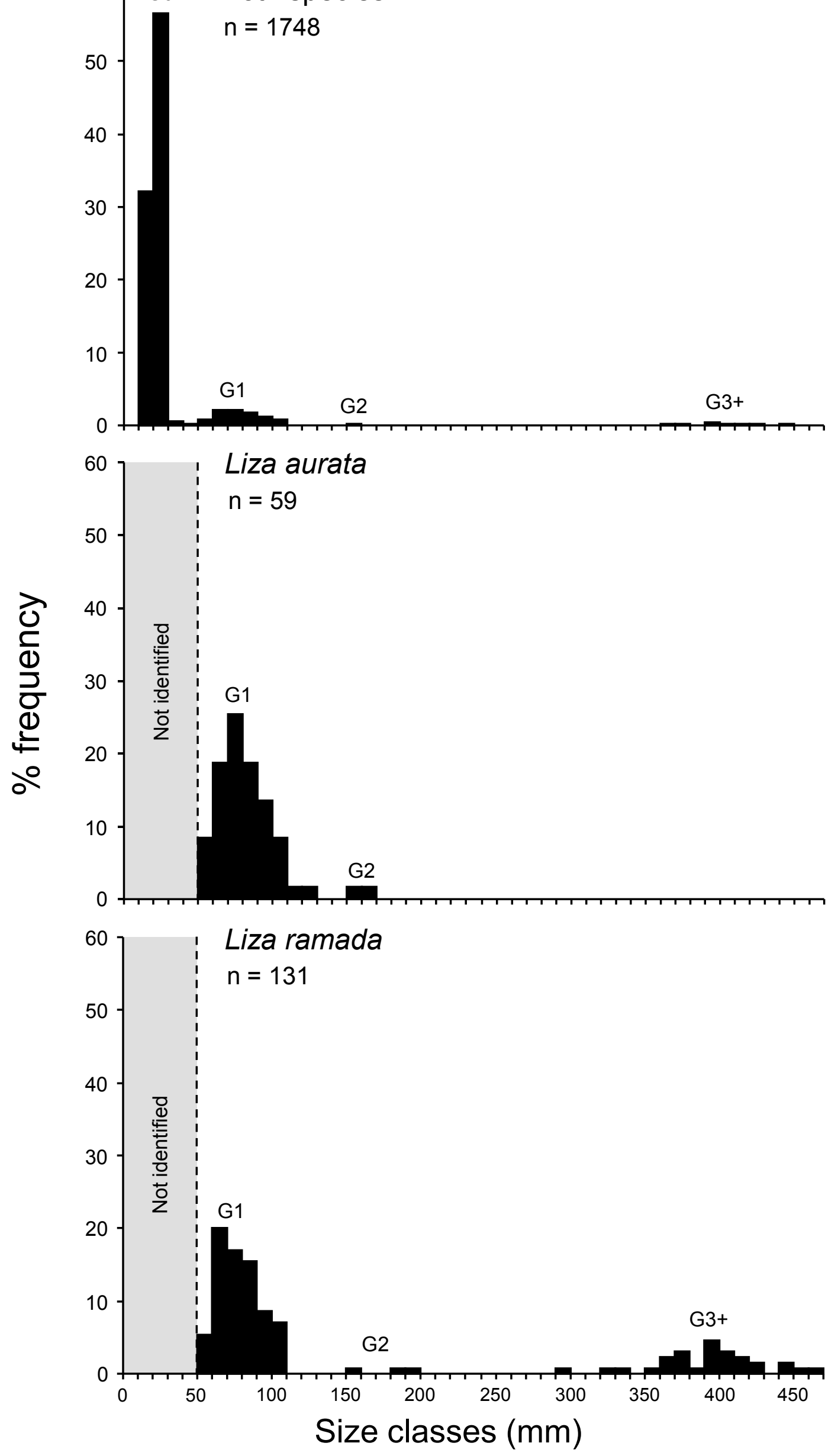
